\title{
Karakterisasi Morfologi dan Skrining Fitokimia Ekstrak Umbi dan Daun Tumbuhan Ginseng (Phytolacca octandra L.)
}

\author{
Intan Sari ${ }^{*}$, Henri' ${ }^{1}$, Eka Sari ${ }^{1}$, Suharyanto $^{2}$ \\ 1Program Studi Biologi, Fakultas Pertanian, Perikanan dan Biologi, Universitas Bangka Belitung, \\ Indonesia \\ 2Balai Pengkajian Teknologi Pertanian, Provinsi Kepulauan Bangka Belitung, Indonesia
}

\begin{abstract}
Ginseng plant (Phytolacca octandra L.) is a wild plant that has the potential to be used as medicine. The morphological characteristics of ginseng plants in Indonesia are different. Therefore, it is necessary to carry out research aimed at characterizing the morphology and phytochemical screening of ginseng (P. octandra L.) leaves and tubers. The research was conducted first by observing morphological characters and screening phytochemical compounds such as alkaloid test, flavonoid test, phenol test, tannin test, saponin test, terpenoid test, and steroid test. The results of the research on the morphological characterization of ginseng ( $P$. octandra L.) were: having a taproot which was modified into a tuber, a round, smooth, red color, pointed leaf shape, the base and tip of the leaf were pointed, buni fruit type, round flat, colored blackish-purple when ripe, a compound flower is located at the end of the branch and has flat, round seeds. Ginseng tubers have triterpenoid and saponin compounds, while the leaves only have saponin compounds. The potential development of ginseng ( $P$. octandra L.) is currently limited as traditional medicine by local people. This is due to limited knowledge in its development efforts and unknown phytochemical content.
\end{abstract}

Keywords: Morphological characterization; phytochemical screening; Phytolacca octandra L.

\begin{abstract}
Abstrak
Tumbuhan ginseng (Phytolacca octandra L.) merupakan tumbuhan liar yang berpotensi untuk dijadikan sebagai obat. Secara karakteristik morfologi tumbuhan ginseng di Indonesia memiliki perbedaan. Oleh karena itu, maka perlu dilakukan penelitian yang bertujuan untuk untuk mengkarakterisasi morfologi dan skrining fitokimia daun dan umbi ginseng ( $P$. octandra L.). Penelitian dilakukan terlebih dahulu dengan mengamati karakter morfologi dan melakukan skrining senyawa fitokimia seperti: uji alkaloid, uji flavonoid, uji fenol, uji tannin, uji saponin, uji terpenoid dan uji steroid. Hasil penelitian karakterisasi morfologi tumbuhan ginseng ( $P$. octandra L.) yaitu: memiliki akar tunggang yang termodifikasi menjadi umbi, batang bulat licin, berwarna merah, bentuk daun menjorong, pangkal dan ujung daun berbentuk runcing, tipe buah buni, berbentuk bulat gepeng, berwarna ungu kehitaman setelah matang, bung majemuk terletak di ujung cabang serta memiliki biji bulat gepeng. Umbi ginseng memiliki senyawa triterpenoid dan saponin, sedangkan pada daun hanya memiliki senyawa saponin. Pengembangan potensi tumbuhan ginseng (P. octandra L.) saat ini masih terbatas sebagai obat tradisional oleh masyarakat lokal. Hal ini dikarenakan keterbatasan pengetahuan dalam upaya pengembangannya dan kandungan fitokimia yang belum diketahui.
\end{abstract}

Kata kunci: Karakterisasi morfologi; Skrining fitokimia; Phytolacca octandra L.

\footnotetext{
* Corresponding Author: Henry, email: biology.henry@gmail.com. Program Studi Biologi, Fakultas Pertanian, Perikanan dan Biologi, Universitas Bangka Belitung, Indonesia
} 


\section{Pendahuluan}

Tumbuhan obat merupakan sumber obat penting yang efektif dalam berbagai macam jenis pengobatan penyakit, terutama dalam pengobatan tradisional (Borokini \& Oluwafemi, 2012). Tumbuhan obat yang ada di hutan kurang mendapat perhatian oleh masyarakat, sehingga pemanfaatan dan pengelolaannya belum dilakukan secara maksimal. Keanekaragaman tumbuhan obat yang belum diketahui di hutan perlu dieksplorasi sebagai informasi dalam pemanfaatan dan pengelolaannya (Ambri et al., 2015).

Tumbuhan ginseng (Phytolacca octandra L.) merupakan tumbuhan liar yang berpotensi sebagai obat dan tumbuhan ini introduksi dari negara Meksiko, Amerika Tengah, Karibia dan Amerika Selatan. Masyarakat mengenal tumbuhan ini sebagai gulma di lahan yang terganggu, area limbah, tepi jalan, kebun, padang rumput, hutan terbuka dan daerah tepian sungai. P. octandra L sudah ditemukan di berbagai belahan dunia, seperti: China Utara, Korea Utara, Amerika Utara, Siberia, Vietnam, Jepang dan Indonesia dengan varietas yang berbeda (Seervi et al., 2010).

Tumbuhan ginseng (P. octandra L.) tersebar di daerah Pulau Bangka dengan jumlah sedikit dan dikenal sebagai tumbuhan liar serta tidak banyak diketahui masyarakat. Tumbuhan ini masih tersebar dengan jumlah yang banyak di luar negeri salah satunya Australia bagian timur Menurut Hunter (2011), tumbuhan ginseng (P. octandara L.) memiliki status konservasi yang tidak terancam (not threatened) dan belum terdaftar di IUCN red list.

Tumbuhan ginseng diketahui memiliki manfaat penting salah satunya ginseng Jawa (Talinum paniculatum Gaertn.) dimana spesies ini mempunyai beberapa khasiat, yaitu: penambah stamina (afrodisiak), obat radang paru-paru, diare, haid tidak teratur, dan melancarkan ASI (Pribadi, 2013). Ginseng Jawa. (T. paniculatum Gaertn.) telah digunakan dalam industri farmasi dan mengandung senyawa saponin, flavonoid, tanin, triterpen atau sterol, dan polifenol. Saponin T. paniculatum Gaertn. terakumulasi di akar. Kemampuan dan efektivitas saponin dalam berbagai pengobatan obat telah terbukti secara ilmiah (Manuhara et al., 2015).

Informasi mengenai kandungan fitokimia tumbuhan ginseng spesies Talinum paniculatum Gaertn. telah banyak dilakukan. Akan tetapi pada spesies Phytolacca octandra L. belum banyak dilaporkan. Informasi mengenai P. octandra L. sangatlah penting sebagai upaya untuk pengembangannya sebagai obat maupun upaya konservasinya. Oleh karena itu, langkah awal yang dapat dilakukan pada spesies P. octandra L. berupa kajian karakterisasi morfologi serta kandungan fitokimianya.

\section{Metode Penelitian}

\section{Waktu dan Lokasi Penelitian}

Penelitian ini dilakukan pada bulan Juni sampai dengan Agustus 2019. Pengambilan sampel tumbuhan ginseng sebanyak tiga individu dengan metode purposive sampling (Jumiarni \& Komalasari, 2017), dengan modifikasi, yaitu: tidak berdasarkan strata atau stadium pertumbuhan, memiliki organ yang lengkap (vegetatif dan generatif), dilakukan secara acak serta pada beberapa individu tumbuhan utuh diambil pada setiap kabupaten di Pulau Bangka. Pengujian fitokimia di lakukan di Laboratorium Biologi dan Laboratorium Dasar Universitas Bangka Belitung.

\section{Pembuatan Herbarium}

Pembuatan herbarium ini dilakukan dengan tujuan untuk memudahkan dalam melakukan identifikasi sampel (Murni et al., 2015). Pada penelitian ini kriteria untuk pembuatan herbarium tumbuhan ginseng ( $P$. octandra L.) yaitu tumbuhan harus memiliki organ vegetatif dan generatif secara lengkap. Herbarium tumbuhan yang dilakukan meliputi akar, batang daun, bunga, buah dan biji. Setiap lokasi penelitian hanya diambil 3-5 rangkap tumbuhan lengkap untuk diamati dan dibandingkan dengan tumbuhan di lokasi penelitian lainnya. Tahapan dalam pembuatan herbarium dilakukan dengan mengkoleksi spesimen, pengawetan spesimen dan mengidentifikasi spesimen. Proses 
identifikasi spesimen ini dilakukan di Herbarium Bogoriense Lembaga Ilmu Pengetahuan Indonesia (LIPI) Cibinong-Bogor.

\section{Karakterisasi Morfologi Tumbuhan Ginseng}

Karakterisasi dilakukan dilapangan dengan mengamati karakter secara morfologi (akar, batang, daun, bunga, buah dan biji), menggunakan buku Morfologi Tumbuhan Cetakan ke-22 karya Tjitrosoepomo (2020), jurnal ilmiah dan referensi pendukung lainnya tentang $P$. octandra L. Hasil pengamatan di lapangan selanjutnya dilakukan dokumentasi dengan menggunakan kamera.

\section{Skrining Fitokimia}

Skrining fitokimia dilakukan sebagai suatu bentuk analisis secara kualitatif yang digunakan untuk menentukan ciri senyawa aktif yang terkandung pada bagian-bagian tumbuhan, sehingga potensi yang bermanfaat dapat dikembangan sebagai obat (Erviani et al., 2019). Metode penelitian fitokimia ini menggunakan metode maserasi, dimana metode ini dilakukan dengan merendam suatu bahan yang berupa simplisia dengan menggunakan suatu jenis pelarut.
Metode maserasi dipilih dikarenakan mampu menghasilkan suatu ekstrak simpilisia dalam jumlah banyak, selain itu metode ini juga mampu menjaga senyawa-senyawa kimia tertentu yang diakibatkan oleh pemanasan (Zhang et al., 2018). Jenis pelarut pada penelitian yaitu pelarut etanol. Adapun jenis-jenis pengujian fitokimia yang dilakukan diantaranya yaitu uji alkaloid (reagen mayer), uji flavonoid (logam Mg dan $\mathrm{HCl}$ pekat), uji fenol $\left(\mathrm{FeCl}_{3} 1 \%\right.$ ), uji tannin (air dan $\mathrm{FeCl} 31 \%$ ), uji saponin (akuades), uji terpenoid ( $\mathrm{HCl}$ dan $\mathrm{H}_{2} \mathrm{SO}_{4}$ ) dan uji steroid (kloroform dan asam asetat anhidrat).

\section{Hasil Penelitian dan Pembahasan}

\section{Morfologi Tumbuhan Ginseng (Phytolacca octandra L.)}

Hasil identifikasi sampel akar, batang, daun, bunga dan buah tumbuhan ginseng di Herbarium Bogoriense LIPI menunjukkan bahwa sampel yang dikoleksi di Pulau Bangka merupakan spesies P. octandra L. dari famili Phytolaccaceae (Gambar 1.). Karakterisasi P. octandra L. dengan spesies pembeda lain dapat dilihat pada (Tabel 1).

\section{Gambar 1}

Karakterisasi morfologi tumbuhan ginseng (Phytolacca octandra L.) (Foto: Dokumentasi Pribadi, 2019)

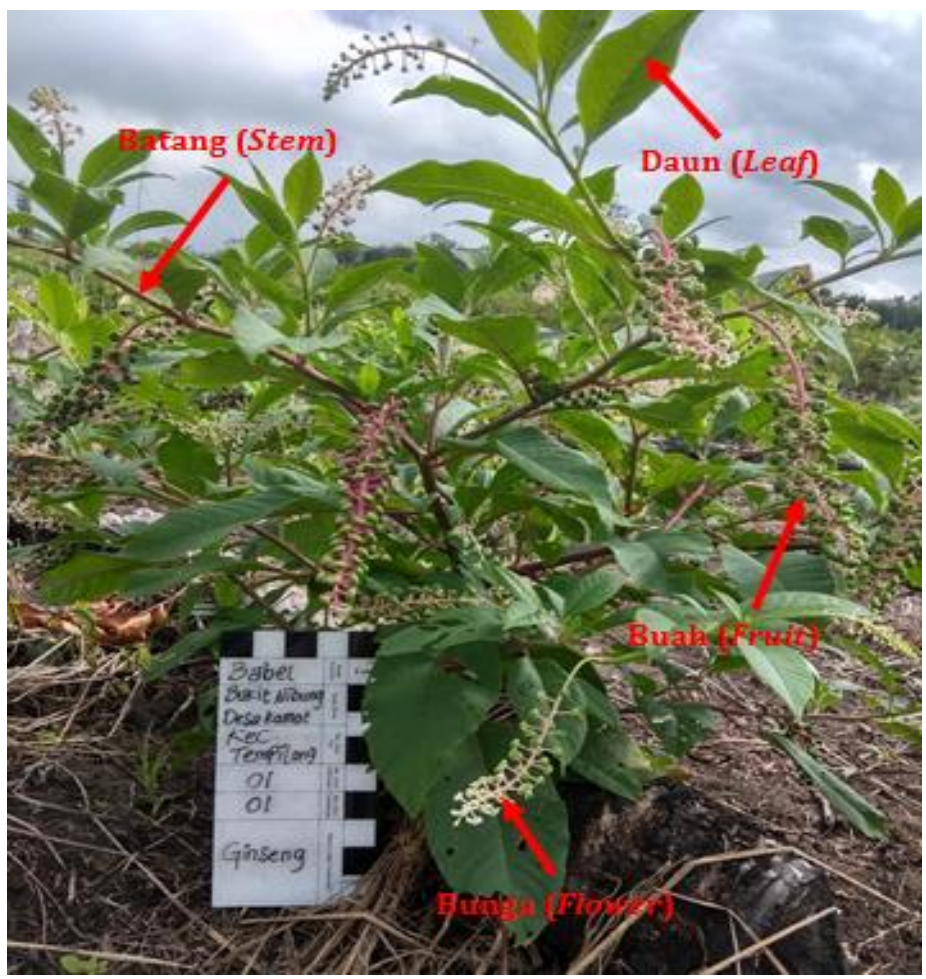




\section{Tabel 1}

Hasil karakterisasi morfologi tumbuhan ginseng (P. octandra L.) di Pulau Bangka dan perbandingannya dengan ginseng (P. octandra L.) di luar negeri

\begin{tabular}{|c|c|c|}
\hline \multirow[t]{2}{*}{ Parameter } & \multicolumn{2}{|c|}{$\begin{array}{c}\text { Perbedaan Karakterisasi } \\
\text { Morfologi Tumbuhan Ginseng }\end{array}$} \\
\hline & Phytolacca octandra L. $*$ ) & Phytolacca octandra L.**) \\
\hline \multicolumn{3}{|l|}{ Akar } \\
\hline Sistem perakaran & akar tunggang & akar tunggang \\
\hline Organ termodifikasi & akar menjadi umbi & akar menjadi umbi \\
\hline Warna organ termodifikasi & putih kekuningan & putih kekuningan \\
\hline Diameter Umbi & $3 \mathrm{~cm}-5 \mathrm{~cm}$ & - \\
\hline \multicolumn{3}{|l|}{ Batang } \\
\hline Bentuk batang & teres: bulat & teres: bulat \\
\hline Arah tumbuh batang & erectus: tegak ke atas & erectus: tegak ke atas \\
\hline Cara percabangan & monopodial & monopodial \\
\hline Permukaan batang & laevis: licin & laevis: licin \\
\hline Warna batang & Merah & Merah \\
\hline Panjang batang & $80 \mathrm{~cm}-1 \mathrm{~m}$ & $1 m-2 m$ \\
\hline Diameter Batang & $1 \mathrm{~cm}-3 \mathrm{~cm}$ & $1 \mathrm{~cm}-3 \mathrm{~cm}$ \\
\hline \multicolumn{3}{|l|}{ Daun } \\
\hline Bentuk daun & elliptic; menjorong & elliptic; menjorong \\
\hline Pangkal daun & acuminate; runcing & acuminate; runcing \\
\hline Ujung daun & acuminate; runcing & acuminate; runcing \\
\hline Tepi daun & entire; rata & entire; rata \\
\hline Permukaan daun & scaber: kasap & scaber: kasap \\
\hline Pertulangan daun & pinnate; menyirip & pinnate; menyirip \\
\hline Tata letak daun & alternate; berseling & alternate; berseling \\
\hline Panjang daun & $4 \mathrm{~cm}-23 \mathrm{~cm}$ & $5 \mathrm{~cm}-25 \mathrm{~cm}$ \\
\hline Lebar daun & $7 \mathrm{~cm}-11 \mathrm{~cm}$ & $1 \mathrm{~cm}-8 \mathrm{~cm}$ \\
\hline Tangkai daun & $2 \mathrm{~cm}-3,5 \mathrm{~cm}$ & $2 \mathrm{~cm}-4 \mathrm{~cm}$ \\
\hline \multicolumn{3}{|l|}{ Buah } \\
\hline Tipe buah & bacca: buah buni & bacca: buah buni \\
\hline Bentuk buah & bulat gepeng dengan 8-9 & bulat gepeng dengan 6-8 \\
\hline Warna buah mentah & hijau & hijau \\
\hline Warna buah matang & ungu kehitaman & ungu kehitaman \\
\hline Diameter buah & $3 \mathrm{~mm}-10 \mathrm{~mm}$ & $0,5 \mathrm{~mm}-8 \mathrm{~mm}$ \\
\hline Jumlah buah & $15-35$ & $10-20$ \\
\hline \multicolumn{3}{|l|}{ Bunga } \\
\hline Tata letak bunga & ujung cabang & ujung cabang \\
\hline Berdasarkan jumlah bunga & $\begin{array}{l}\text { anthotaxis: bunga } \\
\text { majemuk }\end{array}$ & anthotaxis: bunga majemuk \\
\hline Letak mahkota bunga & polysepalus: berlepasan & polysepalus: berlepasan \\
\hline Bentuk mahkota & rotate; memutar & rotate; memutar \\
\hline Warna mahkota & putih kehijauan & putih kehijauan \\
\hline Warna putik & putih kekuningan & putih kekuningan \\
\hline Warna benang sari & putih kekuningan & putih kekuningan \\
\hline Panjang ibu tangkai bunga & $10 \mathrm{~cm}-15 \mathrm{~cm}$ & $8 \mathrm{~cm}-13 \mathrm{~cm}$ \\
\hline Panjang tangkai bunga & $0,5 \mathrm{~mm}-5 \mathrm{~mm}$ & $0,5 \mathrm{~mm}-3 \mathrm{~mm}$ \\
\hline Jumlah mahkota bunga & 5 & 5 \\
\hline Ukuran mahkota & P: 0,4 mm, L: $3 \mathrm{~mm}$ & $P: 2 \mathrm{~mm}-3 \mathrm{~mm}$ \\
\hline Jumlah benang sari & $8-12$ & $8-10$ \\
\hline Ukuran tangkai benang sari & $0,1 \mathrm{~mm}-2,5 \mathrm{~mm}$ & - \\
\hline \multicolumn{3}{|l|}{$\mathrm{Biji}$} \\
\hline Bentuk biji & bulat gepeng & bulat gepeng \\
\hline Warna biji & hitam & hitam \\
\hline Diameter biji & $1 \mathrm{~mm}-2 \mathrm{~mm}$ & $1 \mathrm{~mm}-2 \mathrm{~mm}$ \\
\hline Jumlah biji & $8-9$ & $6-8$ \\
\hline
\end{tabular}

Keterangan: *) Hasil penelitian, 2019 dan ${ }^{* *}$ Hyde et al. 2019 


\section{Morfologi akar}

Berdasarkan hasil pengamatan morfologi akar pada tumbuhan ginseng menunjukkan bahwa tumbuhan ginseng yang didapatkan memiliki akar yang seragam pada beberapa pengamatan morfologi akar, yaitu pada sistem perakaran (akar tunggang), modifikasi organ akar (umbi) dan warna modifikasi organ (putih kekuningan). Menurut Kariuki et al. (2016), bahwa tumbuhan ginseng (P. octandra L.), memiliki morfologi akar, yaitu: berakar tunggang, memiliki akar yang panjang dan membentuk umbi, umbi berwarna putih kekuningan dan diameter umbi $3 \mathrm{~cm}-5 \mathrm{~cm}$.

Menurut Ryan et al. (2016), akar merupakan organ vegetatif tumbuhan yang berfungsi untuk menegakkan batang, menyerap unsur hara, air dalam tanah serta sebagai tempat penyimpan cadangan makanan. Akar ginseng morfologinya hampir sama dengan akar ginseng pada umumnya. Menurut Hyde et al. (2019), memiliki morfologi akar tunggang yang berbentuk silindris, memiliki panjang sekitar $20 \mathrm{~cm}$, berwarna putih kekuningan, kasar, memiliki 2 sampai 3 cabang.

\section{Morfologi batang}

Hasil penelitian morfologi batang pada tumbuhan ginseng menunjukkan bahwa tumbuhan ginseng yang didapatkan memiliki batang yang seragam pada beberapa pengamatan morfologi batang, yaitu bentuk batang (teres: bulat), arah tumbuh batang (erectus: tegak ke atas), cara percabangan (monopodial), permukaan batang (laevis: licin), warna batang (hijau sampai kemerahan), memiliki panjang kisaran $80 \mathrm{~cm}-1 \mathrm{~m}$ dan diameter batang kisaran $1 \mathrm{~cm}-3 \mathrm{~cm}$. Tumbuhan ginseng memiliki batang yang bercabang tegak, tidak berambut, berbentuk bulat licin, batang muda berwarna hijau sampai merah muda dan batang tua berwarna merah (Kariuki et al., 2016). Batang berfungsi sebagai penyalur makanan yang prosesnya dimulai dari bagian akar kemudian ditransfer ke bagian daun serta hasil fotosintesis keseluruh bagian tumbuhan, menopang daun, bunga, dan buah (Wahyu, 2014).

\section{Morfologi daun}

Hasil penelitian morfologi daun pada tumbuhan ginseng menunjukkan bahwa tumbuhan ginsengyang didapatkan memiliki daun yang seragam pada beberapa pengamatan morfologi daun, yaitu bentuk daun (elliptic; menjorong), pangkal daun (acuminate; runcing), ujung daun (acuminate; runcing), tepi daun (entire; rata), permukaan daun (scaber: kasap), pertulangan daun (pinnate; menyirip), memiliki panjang daun $4 \mathrm{~cm}-23 \mathrm{~cm}$, lebardaun $7 \mathrm{~cm}-11 \mathrm{~cm}$ dan panjang tangkai daun $2 \mathrm{~cm}-3,5 \mathrm{~cm}$.

Menurut Eswari et al. (2018), tumbuhan ginseng (P. octandra L.), memiliki daun berbentuk ellip, dengan ujung dan pangkal yang runcing dan warna hijau pada awalnya, tetapi berubah warna kemerahan seiring bertambahnya umur tumbuhan. Menurut Darmawan \& Baharsjan (2010), daun merupakan organ tumbuhan yang memiliki fungsi utama sebagai tempat terjadinya fotosintesis dan mengekspor hasilnya keseluruh bagian tumbuhan.

\section{Morfologi buah}

Hasil penelitian morfologi buah pada tumbuhan ginseng menunjukkan bahwa tumbuhan ginseng yang didapatkan memiliki buah yang seragam pada beberapa pengamatan morfologi buah, yaitu tipe buah (bacca: buah buni), buah buni merupakan buah yang dindingnya mempunyai 2 lapis yaitu lapis luar yang tipis seperti kulit dan lapis dalam yang tebal, lunak dan berair (Tjitrosoepomo, 2020). Bentuk buah (bulat gepeng dengan 8-9 lekukan), dengan diameter $3 \mathrm{~mm}-20 \mathrm{~mm}$, jumlah buah 15-35 buah pada setiap 1 (satu) ibu tangkai, warna buah sebelum matang (hijau muda), warna buah setelah matang (ungu kehitaman).

Menurut Hyde et al. (2019) tumbuhan ginseng $(P$. octandra L.), memiliki buah berbentuk bulat licin, berwarna hijau saat muda, ungu kehitaman saat matang, memiliki tekstur daging buah yang lembut, memiliki 8 (delapan) lobus yang mengandung 8 (delapan) biji dan mengandung tinta ungu sampai kehitaman 
ketika dihancurkan. Buah merupakan organ generatif tumbuhan yang berfungsi melindungi dan membantu dalam proses penyebaran biji (Tamonob, 2017). Menurut Rachmawati (2014), persebaran untuk regenerasi tumbuhan ginseng dibantu oleh manusia dan hewan pemakan buah seperti burung.

\section{Morfologi bunga}

Hasil penelitian morfologi bunga pada tumbuhan ginseng menunjukkan bahwa tumbuhan ginseng yang didapatkan memiliki bunga yang seragam pada beberapa pengamatan morfologi bunga, yaitu tata letak bunga (ujung cabang), berdasarkan jumlah bunga (athotaxis: bunga majemuk), letak mahkota bunga (polysepalus: berlepasan), bentuk mahkota bunga (rotate; memutar), warna mahkota bunga (putih kehijauan), panjang ibu tangkai $10 \mathrm{~cm}-15$ $\mathrm{cm}$, panjang tangkai bunga $0,5 \mathrm{~mm}-5 \mathrm{~mm}$, jumlah mahkota ada 5, warna putik (putih kekuningan), warna benang sari (putih kekuningan), memiliki jumlah benang sari 8-12 dengan ukuran 0,1 mm$2,5 \mathrm{~mm}$.

Tumbuhan ginseng (Phytolacca octandra L.), memiliki bunga-bunga kecil berwarna putih kehijauan, tangkai bunga yang pendek 0,5-3 mm, tumbuh di ujung cabang, setiap bunga memiliki 5 kelopak kecil, memiliki 7-8 benang sari, memiliki ovarium berwarna hijau dengan warna merah muda atau keunguan kecil. Bunga merupakan alat perkembangbiakan generatif tumbuhan, yang befungsi sebagai tempat terjadinya penyerbukan, dimana serbuk sari akan jatuh pada kepala putik sehingga terjadinya pembuahan (Rachmawati, 2014).

\section{Morfologi biji}

Hasil penelitian morfologi biji pada tumbuhan ginseng menunjukkan bahwa tumbuhan ginseng yang didapatkan memiliki biji yang seragam pada beberapa pengamatan morfologi biji, yaitu bentuk biji (bulat gepeng), warna biji (hitam) dengan diameter $0,1 \mathrm{~mm}-0,2$ mm dan jumlah biji 8-9 pada setiap buah. Tumbuhan ginseng (Phytolacca octandra L.), memiliki biji berbentuk bulat gepeng terkandung didalam setiap lobus buahnya, berwarna hitam berkilau dan tekstur yang halus dan licin. Biji merupakan organ generatif tumbuhan yang

berfungsi sebagai bibit penyebaran tumbuhan agar tumbuh jauh dari tumbuhan induknya yang persebarannya dibantu oleh hewan seperti burung (Rachmawati, 2014).

Keseragaman morfologi tumbuhan ginseng tidak memiliki perbedaan yang signifikan dengan tumbuhan ginseng pada umumnya yang tumbuh di negara 4 (empat) musim. Sehingga tumbuhan ginseng tersebut apabila ditanam di negara 2 (dua) musim dan faktor lingkungan yang berbeda, akan memiliki morfologi yang sama. Menurut Hyde et al. (2019), bahwa tumbuhan ginseng ( $P$. octandra L.), tumbuhan yang berasal dari Amerika tropis dan sudah didistribusikan di tempat yang dinaturalisasi secara lokal di negara tropis. Tumbuhan ginseng ini bisa tumbuh di daerah perkebunan, tepi jalan pada musim dingin dan musim panas.

\section{Senyawa Fitokimia Ginseng ( $P$. octandra L.)}

Skrining fitokimia ini dilakukan sebagai tahap awal dalam menentukan kandungan senyawa aktif yang terdapat pada ektraks umbi dan daun tumbuhan ginseng ( $P$. octandra $L$.) (Tabel 2), didapatkan hasil bahwa senyawa saponin dan terpenoid dinyatakan positif pada hasil penelitian ini. Berdasarkan struktur kimianya, metabolit sekunder dapat diklasifikasikan ke dalam berbagai kelompok yang berbeda, yang sebagian besar berbeda dalam hal esensi fungsi ekologisnya (Kennedy \& Wightman, 2011). Kelompok fitokimia terpenting dalam hal ini adalah alkaloid, glikosida, flavonoid, tanin, saponin dan resin yang memiliki khasiat obat. Senyawa saponin pada penelitian ini dinyatakan positif karena hasil uji menunjukkan terdapatnya busa yang bertahan selama 5 menit setelah sampel dikocok pada kisaran 1 menit. Saponin memiliki glikosil sebagai gugus polar serta gugus steroid atau terpenoid sebagai gugus nonpolar sehingga bersifat aktif permukaan. dan membentuk misel saat dikocok dengan air. Saponin merupakan molekul besar dan mengandung hidrofobik yang terdiri dari triterpenoid (30 atom karbon) atau 
steroid (27 atom karbon dengan spirostane 6

cincin atau kerangka furostane 5 cincin).

Tabel 2

Hasil uji fitokimia pada umbi dan daun tumbuhan ginseng (P. octandra L.) dan perbandingan dengan hasil uji fitokimia tumbuhan ginseng (P. octandra L.) di luar negeri

\begin{tabular}{|c|c|c|c|c|c|c|c|c|}
\hline \multirow{2}{*}{$\begin{array}{c}\text { Organ } \\
\text { tumbuhan }\end{array}$} & \multirow{2}{*}{$\begin{array}{l}\text { Jenis } \\
\text { pelarut }\end{array}$} & \multicolumn{7}{|c|}{ Senyawa } \\
\hline & & Alkaloid & Flavonoid & Fenol & Tanin & Saponin & Terpenoid & Steroid \\
\hline \multicolumn{9}{|c|}{ Hasil penelitian } \\
\hline Umbi & Etanol & - & - & - & - & + & + & - \\
\hline Daun & $96 \%$ & - & - & - & - & + & - & - \\
\hline \multicolumn{9}{|c|}{ Referensi (Eswari et al., 2018) } \\
\hline \multirow{3}{*}{ Umbi } & Air & + & + & + & + & - & - & - \\
\hline & Aseton & + & + & + & + & + & - & + \\
\hline & $\begin{array}{l}\text { Petroleum } \\
\text { eter }\end{array}$ & + & + & + & - & + & - & + \\
\hline
\end{tabular}

Keterangan: (-) tidak mengandung golongan senyawa fitokimia tersebut;

$(+)$ mengandung golongan senyawa fitokimia tersebut

Selain itu, pada bagian hidrofobiknya yang terdiri dari beberapa residu sakarida yang terhubung melalui ikatan glikosa (Barbosa, 2014). Senyawa saponin memiliki sifat yang berkorelasi secara amphipathic atau amphiphilic di atas dari molekul-molekul ini karena mereka dibentuk oleh satu gugus hidrofilik dan satu lipofilik dan satu lipofilik (Augustin etal. , 2011).

Menurut Thakur et al. (2011), saponin merupakan senyawa bioaktif yang diproduksi oleh tumbuhan, beberapa organisme laut dan serangga. Senyawa saponin mempunyai peranan sebagai antibakteri, antibiotik dan antijamur (Kayce et al., 2014). Secara kimia, saponin terbentuk sebagai glikosida steroid atau triterpen polisikli, bersifat bipolar dan biosintesis rantai utama saponin melalui jalur (Thakur et al., 2011)

Uji terpenoid dinyatakan positif apabila terjadi perubahan warna ungu atau merah. Uji terpenoid ini, ekstrak etanol tumbuhan ginseng dilarutkan dalam kloroform kemudian ditambahkan pereaksi $\mathrm{H}_{2} \mathrm{SO}_{4} \quad 1 \%$ dan asam asetat anhidrat, menunjukkan hasil positif dengan adanya perubahan warna menjadi merah atau ungu. Menurut Siadi (2012), prinsip reaksi mekanisme uji terpenoid yaitu pelepasan $\mathrm{H}_{2} \mathrm{O}$ dan penggabungan dengan karbokation. Reaksi ini diawali dengan proses asetilasi gugus hidroksil menggunakan asam asetat anhidrat. Senyawa terpenoid banyak digunakan sebagai obat, antiseptik dan antimikrob (Habibi et al., 2018).

Senyawa terpenoid merupakan senyawa yang diproduksi pada berbagai genera tumbuhan, jamur, alga, dan spons. Terpenoid telah diketahui memiliki nilai farmasi yang signifikan sejak zaman prasejarah, karena spektrum aplikasi medis terpenoid yang luas (Jaeger \& Cuny, 2016). Terpenoid dikelompok berdasarkan jumlah unit isopren yang menyusunnya yaitu antara lain: monoterpenoid, diterpenoid, triterpenoid, tetraterpenoid, politerpenoid dan seskuiterpenoid (Ramadani, 2016).

Berdasarkan hasil penelitian Eswari et al. (2018) tumbuhan ginseng (Phytolacca octandra L.) dengan pelarut polar (air), semi polar (aseton) dan non polar (petroleum eter). Dari ketiga jenis pelarut, senyawa fitokimia yang terdeteksi positifnya pun berbeda. Pada pelarut polar (air), senyawa yang positif (+) Volume 4, No 1 (2021) | 61 
mengandung senyawa: alkaloid, flavonoid, fenol dan tannin, sedangkan pada pelarut semi polar (aseton), senyawa fitokimia pada tumbuhan ginseng positif $(+)$ mengandung senyawa: alkaloid, flavonoid, fenol, tanin, saponin dan steroid. Pelarut non polar (petroleum eter), senyawa fitokimia pada tumbuhan ginseng positif (+) mengandung senyawa: alkaloid, flavonoid, fenol, saponin, terpenoid dan steroid. Jika dibandingkan dengan hasil fitokimia pada penelitian ini sangat jauh berbeda, mungkin hal ini dikarenakan pelarut yang digunakan tidak bervariasi dan kadar senyawa kimia pada tumbuhan ginseng yang sedikit sehingga menyebabkan hasil senyawa fitokimianya tidak terdeteksi.

Hasil penelitian tumbuhan ginseng $(P$. octandra L.), bagian yang banyak digunakan oleh masyarakat yaitu: umbi dan daun. Umbi digunakan masyarakat sebagai obat, untuk mengobati sakit pinggang, sakit perut, pegalinu, penambah stamina, sedangkan daun dapat dimanfaatkan dengan cara dibuat sayur. Menurut Muhajidin et al. (2015), tumbuhan ginseng $(P$. octandra L.) secara tradisional banyak digunakan sebagai antifungi, mitogenik, obat stimulan sel limposit darah, antibakteri, perangsang muntah, dan buahnya sering digunakan sebagai bahan pewarna makanan alami karena mengandung senyawa betalain yang memiliki khasiat sebagai obat diantaranya memiliki aktivitas antioksidan yang tinggi.

Tumbuhan ginseng di Pulau Bangka masih dikenal sebagai tumbuhan liar dan belum banyak diketahui oleh masyarakat, sedangkan tumbuhan ini memiliki potensi yang dapat dikembangkan sebagai obat, karena tumbuhan ini mengandung, zat aktif (saponin dan terpenoid). Oleh karena itu, tumbuhan ini perlu dilakukan upaya konservasi seperti budidaya sebab tumbuhan ini keberadaannya sulit ditemukan dan jumlahnya sedikit. Menurut Nurmayulis \& Hermita (2015), salah satu alasan tumbuhan obat Indonesia perlu segera dikembangkan secara serius, baik dalam kapasitas rumah tangga maupun industri karena tumbuhan obat sudah mulai sulit ditemukan dihabitatnya.

\section{Kesimpulan}

Karakteristik morfologi tumbuhan ginseng $(P$. octandra L.) berakar tunggang dan membentuk umbi yang berwarna putih kekuningan. Batang bercabang berbentuk bulat licin, batang berwarna merah muda, memiliki daun berbentuk menjorong, ujung dan pangkal daun runcing, tidak berbulu, daun berwarna hijau tetapi sering berubah warna kemerahan seiring bertambahnya usia tumbuhan. Memiliki buah berbentuk bulat gepeng licin, memiliki diameter buah 3-10 $\mathrm{mm}$, buah muda berwarna hijau dan buah matang berwarna merah gelap, buah bergerombolan (15-35 buah). Tipe bunga majemuk, setiap bunga memiliki lima kelopak kecil, dengan panjang 2-3 mm, panjang tangkai bunga $0,5-5 \mathrm{~mm}$ dan berwarna putih kekuningan. Tipe buah buni berbentuk bulat gepeng, berwarna hijau saat mentah dan ungu kehitaman saat matang dengan jumlah 15-35 buah pada setiap 1 (satu) ibu tangkai, serta memiliki biji berbentuk bulat gepeng, berwarna hitam dan berjumlah 8-9 biji pada setiap buah. Hasil uji fitokimia yang dilakukan, bahwa ekstrak umbi tumbuhan ginseng mengandung senyawa saponin dan terpenoid dan ekstrak daun tumbuhan ginseng mengandung senyawa saponin.

\section{Daftar Pustaka}

Abbasian, B., Azizi, S., \& Esmaeili, A. (2010). Effects of Rat' s Licking Behavior on Cutaneous Wound Healing. 13(1), 242247.

Abiko, Y., \& Selimovic, D. (n.d.). The Mechanism Of Protracted Wound Healing On Oral Mucosa In Diabetes . Review. 10(3), 186191.

Andika, M., Prasko, S., \& Hermien, S. (2014). Pengaruh Berkumur Air Rebusan Cabe Jawa Terhadap Ph Saliva. Kesehatan Gigi, 2(2), 239-244.

Ayuningtyas, G., Harijanti, K., \& Soemarijah, S. (2009). Sekresi saliva menurun dan terjadinya kandidiasis oral pada orang tua ( Penurunan sekresi saliva dan munculnya kandidosis oral pada orang tua ). 1, 6-10.

Brand, H. S., Ligtenberg, A. J. M., \& Veerman, E. C. I. (2014). Saliva and wound healing. Monographs in Oral Science, 24, 52-60.

62 | Volume 4, No 1 (2021) 
https://doi.org/10.1159/000358784

Darmastuti, R. dan D. K. S. (2011). Kekuatan Kearifan Lokal Dalam Komunikasi Kesehatan. Jurnal Komunikasi. Jurnal Komunikasi, 3(2), 233-244.

Destri, C., Nugraha, J., Anatomi, D. P., Kedokteran, F., Surabaya, U. A., Klinik, D. P., Kedokteran, F., \& Surabaya, U. A. (2017). Potensi Jatropha multifida Terhadap Jumlah Fibroblast Pada Aphthous Ulcer. 19(1).

Fajarwati, R., Utami, L., Ip, V. T., Wirohadidjojo, Y. W., Ilmu, B., Kulit, K., Universitas, F. K. Mada, G., \& Sardjito, R. (2015). Efek Saliva Manusia Pada Proliferasi Dan Migrasi Fibroblas Jaringan Kulit Normal. Media Dermato-Venereologica Indonesiana, 42, 2-6.

Gibbs, S., Roffe, S., Meyer, M., \& Gasser, A. (2019). Biology of soft tissue repair: Gingival epithelium in wound healing and attachment to the tooth and abutment surface. European Cells and Materials, 38, 63-78. https://doi.org/10.22203/eCM.v038a06

Hemadi, A. S., Huang, R., Zhou, Y., \& Zou, J. (2017). Salivary proteins and microbiota as biomarkers for early childhood caries risk assessment. Nature Publishing Group, 9(11), 1-8. https://doi.org/10.1038/ijos.2017.35

Kavanagh, K., \& Dowd, S. (2004). Histatins: antimicrobial peptides with therapeutic potential. Journal of Pharmacy and Pharmacology, 56(3), 285-289. https://doi.org/10.1211/002235702297 1

Kumar, B., Kashyap, N., Avinash, A., \& et al. (2017). The composition, function and role of saliva in maintaining oral health: A review. Int J Contemp Dent Med Rev, 1-6. https://doi.org/10.15713/ins.ijcdmr.121

Kusuma, N. (2015). Fisiologi dan Patologi Saliva. Andalas University Press.

Lesmana, H., Alfianur, A., Utami, P. A., Retnowati, Y., \& Darni, D. (2018). Pengobatan tradisional pada masyarakat tidung kota Tarakan: study kualitatif kearifan lokal bidang kesehatan. Medisains, 16(1), 31. https://doi.org/10.30595/medisains.v16i 1.2161

Lewapadang, Wanda, Tendean, Lydia E. N., P. S. A. (2015). Pengaruh Mengonsumsi Nanas (Ananas Comosus) Terhadap Laju Aliran Saliva Pada Lansia Penderita Xerostomia. E-GiGi (EG), 3(2), 454-458.

Mintjelungan, C. N., \& Pangemanan, D. H. C. (n.d.). Xerostomia pada Usia Lanjut di Kelurahan Malalayang Satu Timur. 1-4.

Moleong, L. J. (2012). Metodologi Penelitian Kualitatif. PT Remaja Rosdakarya.

Nanobiotechnol, J., Mi, B., Chen, L., Xiong, Y., Yan, C., Xue, H., Panayi, A. C., \& Liu, J. (2020). Saliva exosomes - derived UBE20 mRNA promotes angiogenesis in cutaneous wounds by targeting SMAD6. Journal of Nanobiotechnology,1-14.

https://doi.org/10.1186/s12951-02000624-3

Oudhoff, M. J., Kroeze, K. L., Nazmi, K., Keijbus, P. A. M., Hof, W., Fernandez-Borja, M., Hordijk, P. L., Gibbs, S., Bolscher, J. G. M., \& Veerman, E. C. I. (2009). Structure-activity analysis of histatin, a potent wound healing peptide from human saliva: cyclization of histatin potentiates molar activity 1000 -fold. The FASEB Journal, 23(11), 3928-3935. https://doi.org/10.1096/fj.09-137588

Pandey, A. K., \& Pandey, A. K. (2014). Physiology of Saliva: An Overview Physiology of Saliva: An Overview.21(1). https://doi.org/10.14693/jdi.v0i0.186

Pertiwi, U. D., \& Rusyda Firdausi, U. Y. (2019). Upaya Meningkatkan Literasi Sains Melalui Pembelajaran Berbasis Etnosains. Indonesian Journal of Natural Science Education (IJNSE), 2(1),120-124. https://doi.org/10.31002/nse.v2i1.476

Publisher, S., Resident, S. S., Maxillofacial, O., \& Divison, S. (2015). Case Report Management of Non Healing Oral Ulcer in Diabetic Patient Using Topical Application of Epidermal Growth Factor: A Case Report. 3(8), 640-643.

Rahmawati, I., Said, F., \& Hidayati, S. (2015). Perbedaan $\mathrm{pH}$ Saliva Sebelum dan Sesudah Mengonsumsi Minuman Ringan. Jurnal 
Skala Kesehatan, 6(1), 11.

Rodrigues Neves, C., Buskermolen, J., Roffel, S., Waaijman, T., Thon, M., Veerman, E., \& Gibbs, S. (2019). Human saliva stimulates skin and oral wound healing in vitro. Journal of Tissue Engineering and Regenerative Medicine, 13(6),1079-1092. https://doi.org/10.1002/term.2865

Saliva, P., Gekko, T., \& Angiogenesis, L. T. (2017). Effect of Tokay Gecko ( Gekko gecko LINNAEUS , 1758 ) Saliva on Angiogenesis During Wound Healing Phase of Autotomized Tail in Common Sun Skink ( Eutropis multifasciata KUHL , 1820 ). 13(2), 253-260.

Sarah J. Lowry, Hillary Blecker, Janice Camp, Butch De Castro, Steven Hecker, Saman Arbabi, Neal Traven, N. S. S. (2017). Possibilities and challenges in occupational injury surveillance of day laborers. Occupational Medicine, 53(4), 130.

Shah, D., Son, K., Kalmodia, S., Lee, B., Ali, M., Balasubramaniam, A., Shukla, D., \& Aakalu, V. K. (2020). Wound Healing Properties of Histatin-5 and Identification of a Functional Domain Required for Histatin5-Induced Cell Migration. Molecular Therapy: Methods \& Clinical Development, 17(June),709-716.

https://doi.org/10.1016/j.omtm.2020.03. 027

Sultan, A. S. (2019). crossm Evaluation of the Antifungal and Wound-Healing Properties of a Novel Peptide-Based Bioadhesive Hydrogel Formulation. 63(10), 1-11.

Susanti, S. (2016). Pemetaan Penyakit Pneumonia di Provinsi Jawa Timur. Biometrika Dan Kependudukan, 5(2), 117124.

Syahrul, D., Dewi, T. P., \& Sulistyawati, I., \& O., G. A. P. (2017). Peranan Madu $15 \%$ Terhadap Peningkatan $\mathrm{pH}$ Saliva Wanita Menopause. Interdental, 9-14.

Torres, P., Castro, M., Reyes, M., \& Torres, V. A. (2018). Histatins, wound healing, and cell migration. Oral Diseases, 24(7), 11501160. https://doi.org/10.1111/odi.12816
Tubert-Brohman, Ivan \& Sherman, Woody \& Repasky, Matthew \& Beuming, T. (2013). ). Improved Docking of Polypeptides with Glide. Journal of Chemical Information and Modeling, 53(9), 1689-1699.

Verrier L. (1970). Dog Licks Man. Lancet, 1, 5.Vila, T., Rizk, A. M., Sultan, A. S., \& JabraRizk, M. A. (2019).

The power of saliva: Antimicrobial and beyond. PLoS Pathogens, 15(11), 10-16. https://doi.org/10.1371/journal.ppat.100 8058

Wahyudi, I. A., Magista, M., \& Angel, M. (2013). Efektivitas Penggunaan Saliva Dibandingkan Povidin-Iodin $10 \%$ Terhadap PenyembuhanLuka Pada Kutaneus Tikus Sprague Dawley The Effectiveness Of Saliva Compare To10 \% Povidin- Iodine Of Healing Injury In Rats Cutaneous Sprague Dawley. Jurnal Universitas Muhammadiyah Yogyakarta, 2(1), 1-12.

Wojcicki, J. M. (2003). Traditional behavioural practices, the exchange of saliva and HHV8 transmission in sub-Saharan African populations. British Journal of Cancer, 89(10),2016-2017. https://doi.org/10.1038/sj.bjc.6601390

Tamonob, A. (2017). Sistem Organ pada Tumbuhan. Retrieved from http//www.file.upi.edu

Thakur, M., Melzig, M. F., Fuchs, H., \& Weng, A. (2011). Chemistry and pharmacology of saponins: special focus on cytotoxic properties. Botanics: Targets and Therapy, 1,19-29. http://doi.org/10.2147/btat.s17261

Tjitrosoepomo, G. (2020). Morfologi Tumbuhan, Edisi Cetakan ke Dua Puluh Dua. Yogyakarta: Gadjah Mada University Press.

Zhang, Q. W., Lin, L. G., \& Ye, W. C. (2018). Techniques for extraction and isolation of natural products: A comprehensive review. Chinese Medicine (United Kingdom), 13(1), 1-26. 